\title{
Erratum to: Assessing the range of newly established invasive species in rivers using probabilistic methods
}

\author{
I. Jarić · G. Cvijanović • A. Hegediš • \\ M. Lenhardt
}

Published online: 12 April 2012

(C) Springer Science+Business Media B.V. 2012

Erratum to: Hydrobiologia (2012) 680:171-178 DOI 10.1007/s10750-011-0914-y

Due to an unfortunate turn of events, the authors' affiliations in the original publication were not correctly displayed. The correct representation of the authors and their affiliations are listed above and below and should be treated as definitive by the reader.

The online version of the original article can be found under doi:10.1007/s10750-011-0914-y.

I. Jarić $(\bowtie) \cdot$ G. Cvijanović · A. Hegediš

Institute for Multidisciplinary Research,

University of Belgrade, Kneza Viseslava 1,

11000 Belgrade, Serbia

e-mail: ijaric@imsi.rs

I. Jarić

Leibniz-Institute of Freshwater Ecology and Inland

Fisheries, 12587 Berlin, Germany

M. Lenhardt

Institute for Biological Research, University of Belgrade,

Despota Stefana 142, 11000 Belgrade, Serbia 